\title{
Three Names of Russian Futurism in Music
}

\section{Lyudmila Gauk}

\section{Introduction}

It is generally accepted that Futurism was initiated in Italy, and then spread throughout the world. All the countries in some degree followed the main principles that the patriarch of Futurism, the Italian writer Filippo Tomaso Marinetti (1876-1944), articulated in his "Manifesto of Futurists" (1909). Despite each country having followed the basic statements of Italian Futurism, they were adopted and shaped in accordance with the local environment. Regarding Russia, it has drawn attention not only to the uniqueness of the Futurists' national branch, but even the championship of Italy is under discussion. The current paper is not aimed at either a construction of the comparative historical chronicles of Futurist Manifestos which appeared in both countries or at challenging someone's uniqueness or primogeniture. The readers have a right to make their own decisions. The goal of the paper is to reflect on the general view of music expressed by the cultural insiders of Russia, the fellows of Futurism, art historians and composers of the turn of the twentieth century. In this connection, three names seem to be essential. They are Nikolai Kulbin (1868-1917), Arthur Lourie (1891-1966), and Mikhail Matyushin (1861-1934). In spite of their different backgrounds, they are united by the movement of the avant-garde to "keep pace with the time."With a degree in physics, Nikolai Kulbin worked for the Imperial Military Medical Academy in Saint Petersburg. He allowed himself to deal in art after retiring from the service when he was middle aged. In January 1898, Kulbin initiated the artistic-psychological group Triangle, whose members participated in many exhibitions advancing avant-garde art. The name of the group was chosen by its founder intentionally. The three vertices of a triangle embody the three facets of the human spirit: Consciousness, Sensation and Will. They all respectively correspond to the trinity of art, namely Plastic Art, Music and the Art of the Word. In early 1908, Kulbin gave a public lecture "Free Art as the Basis of Life: Harmony and Dissonance (On Life, Death and etc.)" (Свободное искусство как основа жизни. Гармония и Диссонанс (о жизни, смерти и прочем)) later

1 The lecture was conducted in the hall of Tenisher's College (from 1889, the successor of Russian State Institute of Performing Art, 1779) for the listeners of the Petersburg Society of Public Universities. 
published as a separate brochure and in its expanded version on the pages of The Studio of Impressionists. ${ }^{2}$ This lecture affected Kulbin's younger colleague, Arthur Lourie who in a few years headed the Futurism movement in music art. Lourie participated in the invention of the basic Manifestos on Futurism art We and the West (1914) and its author's expanded version "We and the West: Speech to the Youths-Artists of Caucasia” (Мы и Запад: Речь к юношам-артистам Кавказа, 1917). He also created his own Futurist aesthetics and expressed it by means of a series of essays. In an attempt to implement his aesthetics principles in music and give freedom to the artists of the avant-garde, Arthur Lourie joined the Soviet regime and led the Music Division of the People's Commissariat of the Enlightenment in Soviet Russia.

Mikhail Matyushin (1861-1934) could be considered in many ways a successor of Lourie. Like the former, he actively participated in constructing a new Soviet culture working along with the well-known painter Kazimir Malevich (1879-1935) for the Organic Culture Department of the State Institute of Art Culture. In order to interest the labour class in the new art and perform the music of the avant-garde, Matyushin articulated the theoretical ideas of Kulbin and Lourie, having invented new instruments able to perform quarter-tone music. His new types of violins were aimed at teaching amateur musicians.

Thus, the thinkings of N. Kulbin, A. Lourie, and M. Matyushin with regard to the art of the Future are explored in sections II-IV respectively. Each section is based on an essay or a set of essays where the author's view is most visible. Kulbin's "Free Art as the Basis of Life" is the key essay of section II. The next section is devoted to Lourie's "Toward a Music of Higher Chromatism." The viewpoints of Matyushin are explored by means of his Guide to Studying of Quarter Tones for Violin, Color Manual: The Laws Covering the Variability of Color Combination, and The Creative Way of an Artist: an Autobiography.

\section{Free art}

Just as Marinetti was esteemed as the father of Futurism in Italy, Nikolai Kulbin (1868-1917) is frequently called the "grandfather of the Russian Futurism." Moreover, the poet and literary critic Vladimir Pyast (1886-1940) named his

2 Nikolai Kulbin, "Free Art as the Basis of Life" [Свободное искусство как основа жизни], The Studio of Impressionists [Студия импрессионистов], ed. N. Kulbin, book 1 (Saint Petersburg: N. I. Butovskaya, 1910), 3-14.

3 Sergei Tyunin (director), documentary Nikolai Kulbin - a Grandfather of Russian Futurism [Николай Кульбин: Дедушка русского футуризма], Series: Stars of the Russian Avant-Garde [Звезды русского авангарда]. Part 3 [Фильм 3], АНО Творческое объединение «Мир искусства» по заказу ГТРК Культура, ГТРК «Культура»: 2008. https://www.youtube.com/ watch?v=L5_bwMVGXM4. 
celebrated contemporary a "preacher of Futurism" or "the chair of Futurism." The articles of Kulbin, particularly "Free Art as the Basis of Life" (1910) were held in the highest regard by a number of scholars, such as Vladimir Markov, John E. Bowlt, Andrey Smirnov, and as early declarations of Futurism. To be fair, it is important to note that despite the accepted opinion, Kulbin preferred to call himself an "impressionist." Vasily Kamensky in the treatise The Path of an Enthusiast (Путь энтузиаста) referred to his memory of the exhibition Impressionists. ${ }^{5} \mathrm{He}$ stated that Kulbin clarified in his welcome speech to the audience, that as we give our impressions on the canvas, we are impressionists. ${ }^{6}$ This fact accords with Markov's statement, that in contrast to Italy, Russian Futurism had an integrated source, and Impressionism was one of the components. ${ }^{7}$

Studying the principles of Kulbin's "Free Art as the Basis of Life," (hereinafter, "Free Art") it is apparent that the author viewed harmony and dissonance not as categories of music but as a physic-mathematic and psychologic-philosophical species. Such a view of a chord in all probability benefited from his experience as a scientist-physiologist. ${ }^{8}$ In short, harmony and dissonance are the dialectical unity of the two sides of the universe. They can frequently be observed in nature, and they are the basis of art. Harmony and dissonance respectively correspond to the two stages of human life, namely death and life itself. Interestingly, death, in accordance with Kulbin's viewpoint, does not mean the end of life as we see it. The death means rest from life. As opposed to such a statement, the active stage of life means life as an activity. The author departs from the psychologicphilosophical couple "dissonance - life" and "consonance — death" and expands it into various levels by means of an associative row (Table 1 ).

4 Vladimir Piast, The Meeting [Встречи], series Russia in Memoirs [Россия в мемуарах] (Moscow: New Literary Observer, 1997), 63, 197.

5 The exhibition Impressionists was organized by N. Kulbin in collaboration with the Burlyuk brothers and V. Kamensky. It was conducted in Petersburg from 8 March 1909 to 12 April 1909.

6 Vasily Kamensky, The Path of an Enthusiast [Путь энтузиаста] (Moscow: Federatsiya, 1931), 100.

7 Vladimir Markov, Russian Futurism: A History (Berkeley and Los Angeles, California: University of California Press, 1968), 2.

8 Nikolai Kulbin received his doctoral degree in 1895. The title of the dissertation was Alcoholism: On the Issue of Ethyl Alcohol and Fusel Oil's Heavy Poisoning Effect on Animals [Алкоголизм: К вопросу о влиянии хронического отравления этиловым алкоголем и сивушным маслом на животных] (Saint Petersburg: Voennaya Tipografiya, 1895). In 1884, Kulbin invented the percutometer, an instrument facilitating diagnostics. 
Table 1. Nikolai Kulbin, The Basic Construct of "Free Art"

\begin{tabular}{|l|l|l|l|}
\hline Realms of Science & Dimensions & Canonical Art & Free Art \\
\hline $\begin{array}{l}\text { Psychologic-philosophical } \\
\text { category }\end{array}$ & $\begin{array}{l}\text { Dialectics of uni- } \\
\text { verse }\end{array}$ & Death & Life \\
\cline { 2 - 4 } & Dialectics of music & Harmony & Dissonance \\
\cline { 2 - 4 } & $\begin{array}{l}\text { Temporal dimen- } \\
\text { sion }\end{array}$ & $\begin{array}{l}\text { Opportunity/ } \\
\text { Potential }\end{array}$ & Impact \\
\hline Physic-mathematic category & Spatial dimension & Resting Energy & Active Energy \\
\cline { 2 - 4 } & Spatial dimension & $\begin{array}{l}\text { Circle (Closed } \\
\text { figure) }\end{array}$ & $\begin{array}{l}\text { Fractured Lines } \\
\text { (Opened figure) }\end{array}$ \\
\cline { 2 - 4 } & Spatial dimension & Symmetry & Dissymmetry \\
\hline
\end{tabular}

To put it simply, death is a symbol of resting energy, moving along the circle, a geometrical shape without beginning and ending. The circle is a symmetrical shape, and its symmetry symbolizes harmony and rest in all respects. To wake hidden energy, harmony needs to be fractured by means of dissonance having the role of impact. Only dissonance is able to curve symmetry, revive the universe, and stimulate life into the active stage from its resting stage. Harmony of death contains merely an opportunity for an activity, that will begin someday, and dissonance strengthens the capacity of life to be revealed. Dissonance confronts harmony and aids in bearing true life. The more active life is, the more dissonance it has. ${ }^{9}$ In other words, dissonance means changing the image of a vicious cycle and releasing the energy captured therein. This statement allows us to assume that Kulbin recognized his free music in a dialectical way and in some sense, as a multidimensional space, when the concept started to attract the attention of painters of that time. Whether done consciously or unconsciously, the author contrasted the triangle "resting energy_circle—symmetry" to the other triangle "active energy - fractured lines—dissymmetry," with both triangles belonging to the spatial dimension. The fourth element of Kulbin's associative row belongs to the temporal dimension. It is an opportunity or potential in the first triangle and an impetus to activity in the second one. Kulbin seems to reflect on the categories of dissonance and harmony in accordance with the new perception of the universe being spaced in four dimensions. While the circle (harmony) is rotating by a certain will (dissonance), the angle of viewpoint is also changing.

9 Nikolai Kulbin, Free Music. Musical Applications of the New Theory of Artistic Creativity [Свободная музыка. Применение новой теории художественного творчества к музыке] (Saint Petersburg: Voennaya Tipografiya, 1909), 3-4. 
This changing resulted in the symmetrical image of the circle turns to a dissymmetrical form of separated lines.

While the arguments continued to proceed, Kulbin paid attention to the issue of resolving dissonance into harmony. He implied a certain passing dissonance, namely the dissonance stated between two consonants. Kulbin called it "harmony of succession" [гармония последовательности] and expected it would be a method to affect perception, senses and the will of the audience. ${ }^{10}$ Making use of dissonance to make an emotional impact has actually been known in music since the end of the sixteenth century. The Italian composer Carlo Gesualdo (1561-1913) was one who forced (compressed) an emotional tension by means of extraordinary dissonances, referred to by James Thomson as a "harmonic leap."11 Kulbin, like many other composers, interpreted dissonance as an impact for either a progression or a change in the harmony (consonance). Taking this statement into account, the notion toward harmony and a conclusion with harmony seems highly natural. The consonance (circle) after a complete rotation (revolution of 360 degrees) through sets of dissonances (fractured lines) will return, after all, to its origin, that is harmony.

In his discourse on free art, Kulbin pointed out that its source is in nature, although it has no intent to copy nature. In a similar way, free music, as an integral constituent of free art, needs to comply with the laws of nature; to be exact, its law of development. ${ }^{12}$ It implies that free music is not confined by merely tonesemitone or a very exact pitch, due to the graduation of pitches, but are much wider and more complex and their acoustic colors are diverse and wealthy. To bring music composed by man closer to the level of music developed by nature, Kulbin suggested using "close connections of tones" 13 or more precisely, a "close combination" ${ }^{14}$ of tones [тесные сочетания тонов], namely the adjunct tones of a scale, of quarter tones and even quaver-tones. To promote his suggestion, the author, probably referring to the Great Perfect System of ancient Greece, stressed that ancient music used quarter tones widely in the so-called enharmonic genus, and nowadays they are still applied in the music of India and to some cultures of the Far East. ${ }^{15}$ To reject quarter tones and other close connections of tones, man makes subtle graduations of light and colors in a poorly painted work, and

${ }_{10}$ Kulbin, "Free Art as the Basis of Life," 5-6.

${ }^{11}$ James C. Thomson, Music through the Renaissance, 2nd ed. (Dubuque, Iowa: Wm. C. Brown Publisher, 1984), 216.

12 Kulbin, "Free Art as the Basis of Life," 15-16.

${ }_{13}$ The term was suggested by Andrei Smirnov in Sound in Z: Experiments in Sound and Electronic Music in Early 20th Century Russia, ed. Matt Price (London: Koenigs Books, 2013), 24.

${ }^{14}$ The term was suggested by Charlotte de Mille in the collection of essays Music and Modernism, c. 1849-1950 (London: Cambridge scholars publishers, 2011), 89.

15 Kulbin, "Free Art as the Basis of Life," 16. 
this prevents him from more precisely presenting the universe, human life, and nature by means of music.

Importantly, Kulbin, in contrast to his Italian colleague Luigi Russolo (1885-1947), was very far from refusing the current music system all together. He discussed the need to recognize that quarter-and-lesser-tones could be utilized; their application would aid in expanding the coloristic realm of music and approach closer to the other fine art forms ${ }^{16}$ According to Kulbin, quarterand-lesser-tones could be notated as "a drawing with descending and ascending lines." ${ }^{17}$ Such a drawing would in all probability look very similar with a notation which Russolo used in 1914 in his piece for intonarumori "Awakening of a City" (Figure 1).

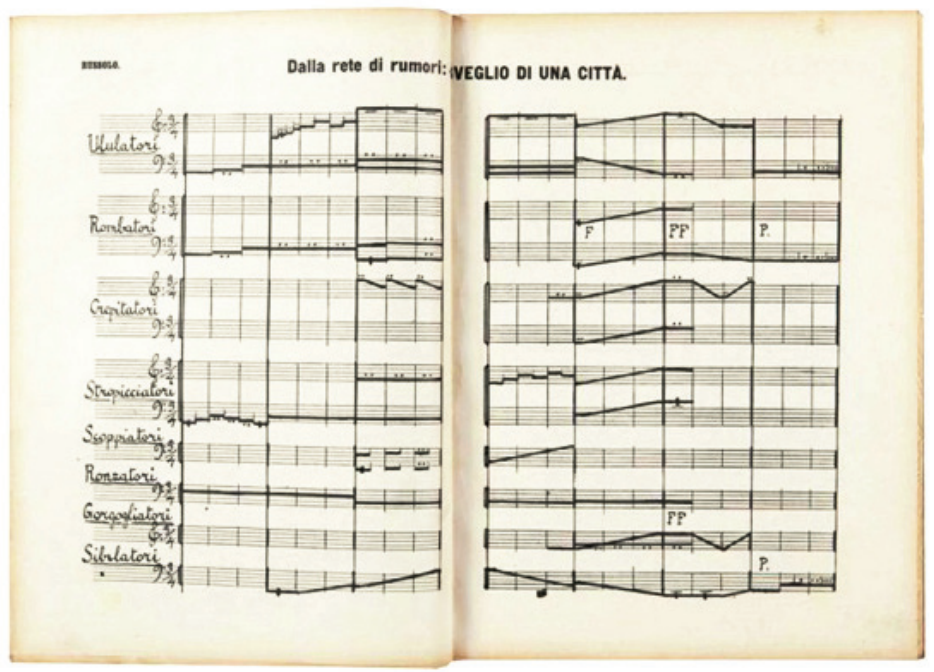

Figure 1. Excerpt from the score for "Risveglio di una città" ("Awakening of a City"), to be played on intonarumori (noise machines). Lacerba (1 March 1914), 72-73 ${ }^{18}$

Speaking of the issues of the theory of art, Kulbin pointed out that "nowadays, there are very few loving hearts [that are] able to read the thoughts of art

\footnotetext{
${ }^{16}$ Ibid., 18.

17 Kulbin, "Free Art as the Basis of Life," 20.

${ }_{18}$ The Museum of Modern Art Library, New York. (C) Luigi Russolo Estate. Photo Marcin Muchalski, (C) Diamond Short Studio, https://www.moma.org/interactives/exhibitions/2012/ inventingabstraction/?work=240
} 
conveyed in the great works of the past. The crowd antagonizing old artists is deaf to their art's messages." ${ }^{19}$

In conclusion, Kulbin stated that art was indivisible; in other words, a unified art should be perceived in an integrated complexity. Colors are in harmony, for example, with words and pitches. He suggested a plan for the practical realization of his free music. The plan consisted of suggestions for establishing a Society of Free Music, which would establish guidelines for the use of the instruments' tuning in accordance with the case of "a close combination of tones" and addressed issues of the notation of music with such microtones. It is relatively difficult to imagine how the musical community reacted to such a plan. Nevertheless, Kulbin's paper "New Currents in Art" was presented at the All-Russian Congress of Artists in Petrograd on 28 December 1911. The minutes of the Congress contained an entry of a certain Mr. Prokhorov (probably, the painter Semen Prokhorov) ${ }^{20}$ who rejected the plan questioning whether a human could differentiate tones lesser than a semitone. Kublin confronted another painter, Gerasim Magula (1873-1923), arguing that an artist had the right to express himself by means of forms and the ways he felt necessary. ${ }^{21} \mathrm{It}$ is at this Congress that Kulbin's idea of dissonance as an impetus of energy in music was illustrated. The pianist and professor of Saint Petersburg Conservatory Anatoly Drozdov (1883-1950) played the piano work "In the Hermitage" (В скиту). The pianist Anatoly Drozdov is the future piano teacher of Arthur Lourie, who would later become the leader of Futurism music in Russia of the 1910s and whose concepts will be dissected in the following section.

\section{Toward a music of higher chromaticism}

Detlef Gojowy stated that Arthur Lourie is considered "a generator of new musical language." 22 Being inspired by the idea of Kulbin regarding quarter tones in music, Lourie started his "modern music writing" since as early as 1910 . The practical implementation of modern music writing comprises not simply the creation of such compositions, but also at least two tasks: notation of quarter

${ }_{19}$ Kulbin, "Free Music," 9.

20 The painter Semen Prokhorov (1873-1948) was a student of the outstanding Russian painter Ilya Repin (1844-1930).

${ }^{21}$ Nikolai Kulbin, "New Currents in Art," The Works of All-Russian Congress of Artists in Petrograd: December, 1911 January, 1912 [Труды Всероссийского съезда художников в Петрограде: декабрь 1911-январь 1912], vol. 1 (Petrograd: Tovarischestvo R. Golike and A. Vil'borg, 1914), 40. http://omskmark.moy.su/publ/essayclub/noobiblion/0000001_b_trudyvsh1912_1_1914/111-1-0-3042.

${ }^{22}$ Detlef Gojowy, “Weiteres zu Arthur Lourié," Musikgeschichte in Mittel-und Osteuropa, no. 5 (1999): 99. 
tones and adaption of existing instruments or invention of new ones, which would be able to reproduce quarter tones or even lesser ones.

The earliest experience of Lourie resulted in a few compositions, the most known among them being "String Quartet with Microtones"(1910) and "Prelude for Piano with Higher Chromatism” (op. 12, No. 2, 1912). In order to prove and explain the new notation to audiences, Lourie wrote the essay "Toward a Music of Higher Chromatism," which was written the same year as "We and the West" but printed a year later in the first issue of the cultural almanac The Archer (Стрелец, 1915). This small essay states that the "introduction of quarter tones into music, in a full sense, is the beginning of a new organic era going beyond existing musical forms." ${ }^{23}$ Developing Kulbin's idea to keep safe existing notation, he suggested marks for a quarter-sharp [quartiese], a quarter-flat [quart'moll] and a half-natural, which cancels both previous ones. Those symbols resembled the digit four in the common, mirror, and inverted manners (Table 2).

Table 2. Lourie, Symbols for the Quarter tone Notation

\begin{tabular}{|c|l|l|}
\hline Symbol & Name of origin & Meaning \\
\hline \multicolumn{1}{|c|}{} & Quartiese ${ }^{24}$ (demisharp) & Raises the pitch of a note by one quarter tone \\
\hline & Quart'moll (demiflat) & Lowers the pitch of a note by one quarter tone \\
\hline & Demi-becarre (deminatural) & Cancels a demiflat or demisharp \\
\hline
\end{tabular}

The system of the quarter-tone notation by Lourie is focused on simplifying the record of a score. The author insisted on using the existing notation with a five-line staff and common harmonic system. The Prelude for Piano with Higher Chromatism, that exemplified the suggested symbols, was placed at the end of the essay. The Prelude notated on three-staves remained in Skryabin's manner. Notably, the composer used in the final cadence of his piece a canonical bass line V-VI-V-I tended to E major. This means that Lourie led the musical development of his piece through dissonances to the solid tonal center. Such a consequence is well within Kulbin's concept of harmony of succession where

${ }^{23}$ Arthur Lourie, "Toward a Music of Higher Chromatism" [К музыке высшего хроматизма], The Archer [Стрелец], ed. Alexander Belenson (Petrograd: Strelets, 1915), 81.

${ }^{24}$ Lourie called the symbols for quarter-notes in the French manner: Quartiese, Quart'moll, and Demi-becarre as Russia adapted the names for these music symbols from France. In Russian: полудиез, полубемоль, полубекар. 
dissonance aimed to go to consonance that made dissonance to be considered as a passing harmony.

Lourie stated that the central focus of music art is not the idea itself, or a particular ideology but the form through which the idea is adequately expressed. The dispute about the priority between form and its content deduced in both are not separated and are equally interconnected. This means the content cannot exist without the proper form and the form is nothing if there is not content. The new form cannot be made consciously, which means using a predefined model. It is formed naturally when the necessity is required. To create a new form has no connection with the recipe of the past, but with a personal view of the universe, which is unique and separates the artist from the artisan. ${ }^{25}$

To play the micro-chromatic music, Lourie attempted to invent a new type of piano that would have two levels of strings and a doubled three-color keyboard, ${ }^{26}$ which according to the Russian scholar V. Ishmeeva would be sufficiently complicated in use and non-universal. ${ }^{27}$ The creation, however, of the new type of piano was only intentional. The musicologist Ishmeeva additionally claimed that Lourie's quarter tone symbols were not unique. ${ }^{28} \mathrm{It}$ is not all that difficult to counter this argument since many composers created symbols for quarter tone notation in a similar way: one symbol for one operation. Furthermore, there is still no way to perform the quarter-tone music playing instruments with a common tune. Lourie's concept of quarter-tone notation undoubtedly warrants attention and even if it is unrealized in practice, can be considered "a remarkable exponent of musical experimentation." ${ }^{29}$

\section{Unified Art}

Mikhail Matyushin (1861-1934), who was around Kulbin's age and a contemporary of Lourie, also based his ideas on the concept of nature, as reflected in the discussion of "Free Art" by Nikolai Kulbin. His theoretical-practical works on quarter-tone notation and creation of new instruments were significant in the development of the interrelation between different art forms. Mikhail Matyushin, like Kulbin, was of a multidisciplinary background as he was not only a composer,

25 Arthur Lourie, "Phenomenon and Noumenon in Music" [Феномен и ноумен в музыке], Airways [Воздушные пути], no. 4 (1965): 159.

${ }^{26}$ Benedict Livshits, One and a Half-Eyed Archer [Полутораглазый стрелец], ed. P. Nikolaeva (Leningrad: Sovetsky Pisatel, 1989), 464.

${ }^{27}$ Victoria Ishmeeva, "Quarter-tone Notation in Russian Music of the Early $20^{\text {th }}$ Century." The News: Herzen University Journal of Humanities E' Science, no. 118 (2009): 253.

${ }^{28}$ Ibid., 253.

${ }^{29}$ Larry Sitsky, Music of the Repressed Russian Avant-Garde, 1900-1929 (London: Greenwood Press, 1994), 87. 
but also a violinist and painter. He focused on the topic of making separate forms of arts as a whole, trying to unify them. Matyushin was fond of microtonal music, which led him to attempt to invent new musical instruments with quarter-equal temperament. First of all, as a violinist, ${ }^{30}$ he was interested in how microtonal music could be played with string instruments. He presented the topic in his brochure Guide to Studying Quarter Tones for Violin (Руководство к изучению четвертей тона для скрипки) issued in $1915 .{ }^{31}{ }^{32}$ To designate quarter tones, which Matyushin named as doubled chromatism, one had to divide semitones into two quarter tones. An octave, therefore, consisted equally of twenty-four quarter tones rather than the twelve, as commonly accepted in music practice. Secondly, the issue of the Guide to Studying Quarter Tones for Violin (hereinafter Guide) was expanded and printed in 1918. Here the author expressed his thoughts on the quarter-tone notation. In its short preamble, entitled "To the Guide of New Divisions of a Tone” (К руководству новых делений тона) he stated that the main symbol of his notation is a hook [kryuk], which is widely used in the Russian stolp notation. A note having an upper hook means ascending a pitch on a quarter tone. In a similar way, a note with a lower hook means descending on a quarter tone ${ }^{33}$ (Figure 2).

1 e y

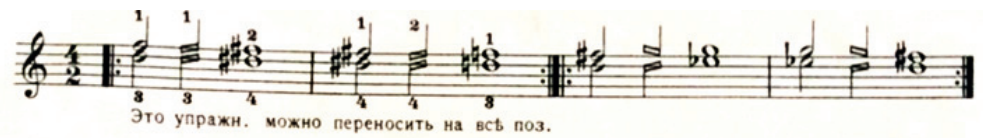

$2 \div$ yпp.

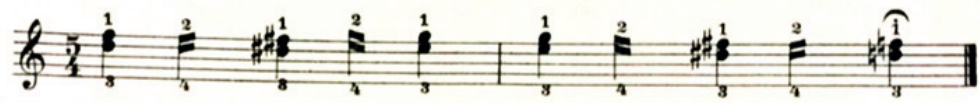

Figure 2. Excerpt from M. Matyushin, Guide to Studying Quarter Tones for Violin

${ }^{30}$ Mikhail Matyushin graduated from Moscow Conservatory in 1881. Along with working for Petersburg Court Orchestra (1881-1913), he studied painting at a few institutions. Among them were School of Drawing of the Artists Encouragement Fund (1894-1898), Studio of Y. F. Tsionglinsky (1903-1905), and School of E. N. Zvantseva (1906-1908). After graduating in painting, Matyushin started working at the Academy of Arts (1918 to 1926), and later headed The Department of Organic Culture of the Institute of Artistic Culture (1923-1926). Matyushin created his own Theory of Organic Culture based on a broadened perception of space and color. In addition, he was co-initiator in the establishment of the society Union of Youth (1910). His disciples and followers comprised the group Zorved (1923), and the Collective of Broadened Observation (KORN, 1930).

${ }^{31}$ Mikhail Matyushin, Guide to Studying Quarter Tones for Violin [Руководство к изучению четвертей тона для скрипки] (Petrograd: Zhuravl, 1915), 1-7.

${ }^{32}$ Matyushin mistakenly noted the issue year of the Guide as 1914. Mikhail Matyushin, The Creative Way of an Artist: an Autobiography [Творческий путь художника: автобиография], ed. A.V. Povelihina (Kolomna: Muzei Organicheskoy Kulturï, 2011), 75.

${ }^{33}$ Matyushin, Guide to Studying Quarter Tones for Violin, 3. 
Note:

$\uparrow$ means descending a note by a quarter tone

means ascending a note by a quarter tone

In order to simplify the visual perception of the score, Matyushin discontinued using symbols such as a flat or a sharp for quarter tones and abandoned key signatures all together. Apart from the new notation symbols, he suggested a few exercises aimed at solving certain technical tasks when playing a violin tuned to quarter tones.

Working on quarter-tonal compositions, Matyushin "recognized the benefit that could be derived from the interconnection of sounds." ${ }^{34} \mathrm{He}$ focused his search on three sources: non-chord structures of harmony, the sound itself, and the production of required sonority through compound combinations of sounds. Through these resources, the voice of nature could be revived and represented to the audience in a new way. In his autobiography The Creative Way of an Artist, Matyushin reminisced:

I recognized the new resource of the sound of noise freely moving in diverse voices. This sound of noise had died for music before, but now it has been resurrected. I intuitively approached the building of compound sounds. Such sounds as the howl of the wind, steps, and beats in a variety of repetitive rhythms. I expanded the range of timbres from the roar of an injured gorilla to the cheeps of a nestling, a factory site, and the roar of an engine. In the city we constantly hear the major or minor seconds together or even in threes. These dissonances are not of 'Bach's temperament,' but even so they are in our ears. We have adapted to listening to them and, moreover, we hear them as conformed harmonies, namely consonances. ${ }^{35}$

In summary, Matyushin's perception of the concept of dissonance by today's man has been changed. Dissonance is considered a consonance rather than a complete discord. Such a concept is not a new one in music practice. It is sufficient to be reminded that for a long while a perfect fourth was considered dissonance.

Matyushin attempted to implement Kulbin's personal quest to unify all forms of art in one whole. In order to put this idea into effect, he departed from the issue of how color and shape were interrelated. Matyushin, in a similar way to Kulbin, recognized the circle as a very harmonic geometrical shape. This caused

${ }^{34}$ Matyushin, The Creative Way of an Artist, 76.

${ }^{35}$ Ibid., 76-77. 
him to choose it for studying how a color altered a man's perception of the shape of an image. The investigation resulted in the following conclusion. Cold colors of the color spectrum have a tendency to strengthen facets and generate angles in a circular shape. In contrast, warm colors make sharp molds plumper, so their corners lose their angularity. One can also note that color modifies the shape differently according to which orientation, vertical or horizontal, a shape has. ${ }^{36}$

To make his research more integral, Matyushin continued studying the interrelation between certain pitches and colors. He was inspired by "Colored Music" presented by Kulbin in the last section of his article "Free Music". Whereas Kulbin described the natural phenomenon of Nikolai Rimsky-Korsakov's chromesthesia (sound-to-color synesthesia), Matyushin studied associative analogies between pitch and color through scientific experimentation. When he headed the Organic Culture Department of the State Institute of Art Culture (1923-1926) ${ }^{37}$ in Petrograd, his goal, according to the Russian art critic Alla Pavelihina (1927-), was to obtain samples or to clarify the close interrelation "between the basic resources of plastic language - shape and color." ${ }^{88}$ Specifically, from 1926, Matyushin expanded the scope of his research and added sound to the couple shape-color. He found that color is differently altered when a pitch ascended or when pitch descended. In other words, a change in pitch affected the change of the color spectrum and vice versa. Such an inference between soundcolor is shown in Figure 3, entitled Futurist Notation (Ноты Будетлянские). ${ }^{39}$ This excerpt is from the opera $A$ Victory over the Sun,${ }^{40}$ based on a text by A. E. Kruchenykh. The opera was designed by K. S. Malevich and staged in Luna Park in Saint Petersburg in 1913. This excerpt from the score was placed at the very end of the opera, that is, after the bold doubled bar line.

${ }^{36}$ Mikhail Matyushin, Color Manual: The Laws Covering the Variability of Color Combination [Справочник по цвету: Закономерность изменяемости цветовых сочетаний] (Moscow: D. Aronov, 2007), 33-34.

37 The State Institute of Art Culture was established in 1923 under Petrograd State Museum Art Culture. It was focused on the study of contemporary currents in art. The institute had five departments: 1) Department of General Ideology [Отдел общей иделогии] headed by Pavel Philimonov and later by Nikolai Punin; 2) Department of Theory and Practice [Отдел формально-теоретический и практический] renamed as Department of Painting [Отдел живописный] headed by Kazimir Malevich; 3) Department of Cultural Artifacts [Отдел материальной культуры] headed by Vladimir Tatlin and from 1925 by Nikolai Seyetin; 4) Department of Painting Methods [Отдел техники живописи] renamed as Department of Science Experience [Экспериментальный отдел] headed by Pavel Mansurov; 5) Department of Organic Culture headed by Mikhail Matyushin.

${ }_{38}$ Matyushin, The Creative Way of an Artist, 13.

39 Ibid., 322.

${ }^{40}$ See the opera A Victory over the Sun by M. Matyushin in English: https://www.youtube.com/ watch?v=iZ0bMBy3dCo. 

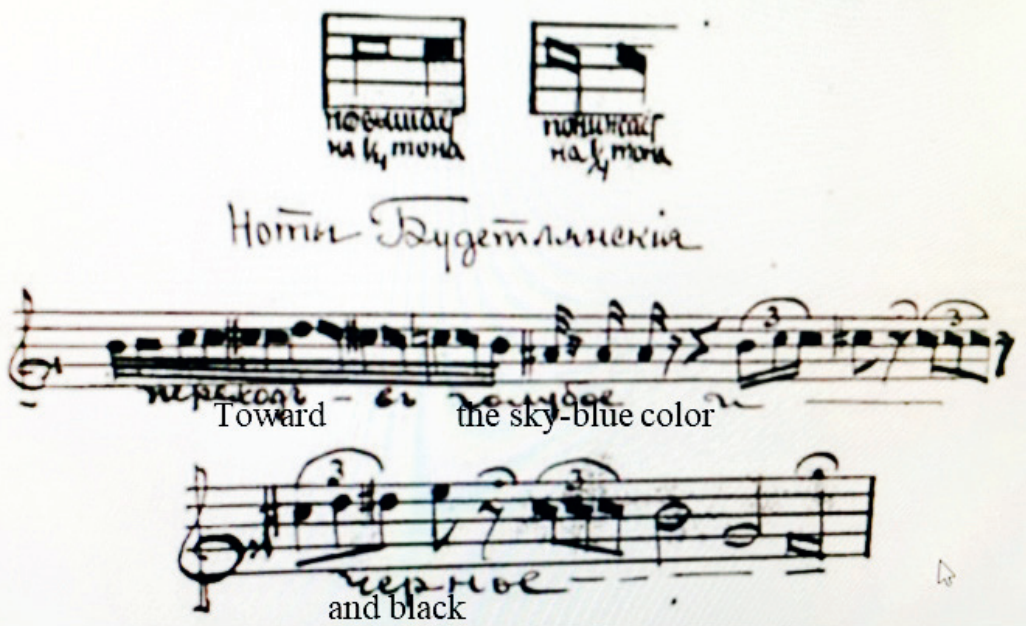

Figure 3. Excerpt from M. Matyushin, opera A Victory over the Sun ${ }^{41}$

Note:

$\lceil$ means ascending a note by a quarter tone

Ymeans descending a note by a quarter tone

In comparison with the Guide (Figure 2), it seems that Matyushin had changed the symbol for ascending a quarter tone. Here, this symbol has no slant. The Russian researcher Viktoriya Ishmeeva, quoting Matyushin's words in the Guide, stated that his symbols were based on the stolp notation, which was widely applied in the music manuscripts of the Russian Orthodox Church. I intentionally exemplified a few excerpts from the manuscripts using the stolp notation (Figure 4 and 5)

${ }^{41}$ Matyushin, The Creative Way of an Artist, 322. 


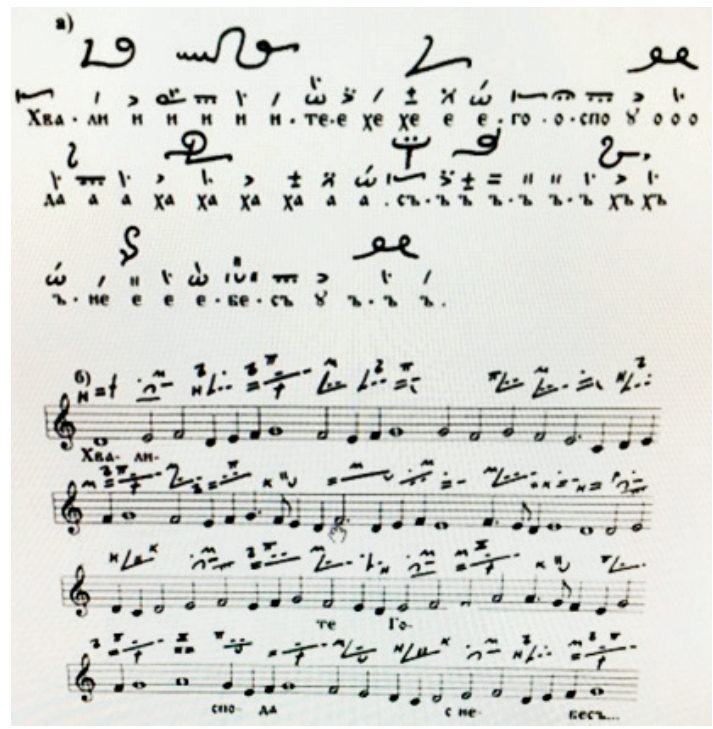

Figure 4. Stolp notation of the Russian Orthodox Church, Znamenny Chant of the XVII century ${ }^{42}$

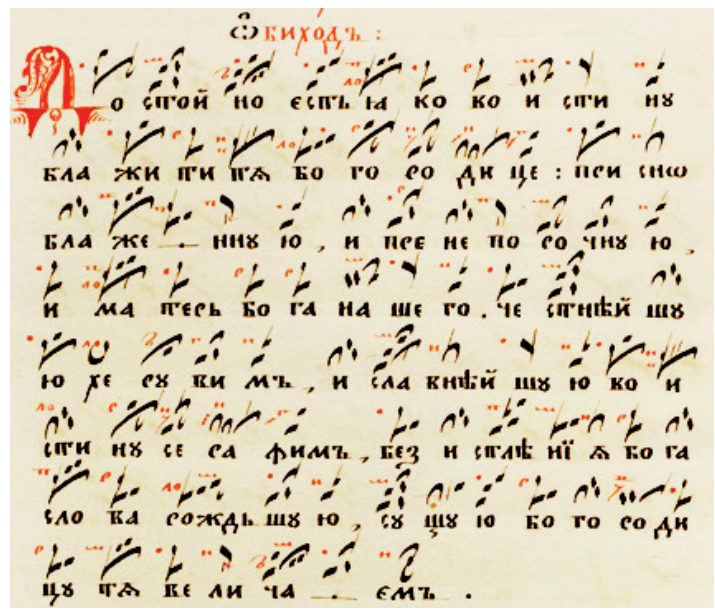

Figure 5. Stolp notation of the Russian Orthodox Church, The Chant "Obikhod"43

${ }^{42}$ Galina Pozhidaeva, The Vocal Traditions of Ancient Russia [Певческие традиции Древней Руси], (Moscow: Znak, 2007), 49.

43 The Alphabet and the Key to the Circle of Church Stolp Notation [Азбука и Ключ к кругу церковного знаменного или столпового пения], Manuscript, XIX century, 120, Russian National Library, https://dlib.rsl.ru/viewer/02000001001\#?page=120 
To be fair, there is no similarity between the symbols used by Matyushin and the Russian stolp notation. It seems that Matyushin borrowed his symbols from the European mensural notation or Kievan square-note music notation, not from the stolp notation. Hence, disregarding the discussion about the source of such symbols, one could note that the composer exemplified the interrelation between a pitch of sound and color pair. According to the author, when sound descended, the color became warmer, whereas when it ascended, the color tends to be of a colder spectrum. This discovery led him to develop a coloristic scale, which he then presented in Color Manual: The Laws Covering the Variability of Color Combination (Справочник по цвету: Закономерность изменяемости цветовых сочетаний). The scale consisted of the eight degrees of colors. As each degree of color has two color-overtones, such a coloristic triangle could be called a color triad. Matyushin explained his viewpoint as follows:

Usually, we do not pay attention to the fact that $\mathrm{C}$ consists of a combination of different pitches. When practiced, you can hear approximately eight pitches that fill up C. The same thing happens with color. Whether the color is bright or dark, it always has some additional sub-color, and it is not just one, but two, three, or even more. And these colors are near or around a basic color. They can be seen with gradual practice and exercise of one's eyes. In a similar way with music, if the first overtone, an octave, and the second one, a fifth, could be applied to the color, than the fifth has the meaning of the first additional color to the basic octave. For instance, the fifth for the red color is blue-green, or the fifth for the blue color is yellow. The following overtones are a third and a seventh, in terms of color. The overtones of those sounds would be respectively presented in the followed color, for example, orange-yellow and violet. Such pitch-and-color overtones are the multiplicity of a sound and color in the seeming whole. This makes the sound and color so fascinating. ${ }^{44}$

Matyushin believed that colored hearing exists naturally and a man is able to benefit in his practice, particularly to strengthen the results of a certain action or to expand the limits of a theatre's decoration that will have a more spectacular effect. ${ }^{45} \mathrm{He}$, along with other Russian avant-garde musicians, was attracted by the idea of reflecting multi-dimensional space in art. Matyushin particularly admired the ideas of the philosopher Pyotr Ouspensky (1878-1947), "the primary Russian advocate of the fourth dimension" 46 and followed him by writing a few articles such as "On the Fourth Dimension" (О четвёртом измерении, 1915)

\footnotetext{
${ }^{44}$ Matyushin, The Creative Way of an Artist, 149.

45 Ibid., 144.

${ }^{46}$ Linda Dalrymple Henderson, "The Image and Imagination of the Fourth Dimension in Twentieth-Century Art and Culture," Configurations, vol. 17, no. 1-2 (Winter 2009): 148 (Baltimore, Maryland: The Johns Hopkins University Press, 2009).
} 
and "The Experience of an Artist of the New Space" (Опыт художника новой меры, 1926). There is no specific reference to Matyushin attempting to input the concept of four-dimensional space in music.

\section{Conclusion}

In summary, the above-mentioned literature of the Russian and Italian Futurists demonstrates that individuals from both countries attempted to create a new art required for the new time, but went about achieving this in different ways. Kulbin and Matyushin, similarly to their Italian contemporaries, aimed at making art closer to human life. In contrast to Italian colleagues, they adhered to the national philosophical idea of uniting all forms of art in one whole and attempting to find it through various experiments. Such an approach to art required "crossdisciplinary" artists, who were able to combine knowledge from each field of art and science. In other words, Russian theoreticians of musical Futurism, in accordance with the philosophical ideas of the Silver Age, recognized that art is a syncretic product of the personality of its author. They stated that an architect, musician, and engineer collaborating in the new society could create a masterpiece of this new integrated art. ${ }^{47}$

Many adherents of the new Futurist art, including Matyushin and Lourie, accepted the new political regime in Soviet Russia. As the new State emerged, the artists faced the choice of whether to leave the country or adapt to its new requirements.

The Russian theoreticians of Futurism in music, in contrast to their Italian counterparts, had no negation, however, of the art of the past. They believed the latter was a kind of alphabet [азбука], which needed to be learned in order to perceive the message from the future. Starting with Kulbin, the Futurists followed the path of expanding the coloristic scope of music, making the texture more sophisticated, and rearranging compositions while attempting to reflect the new principles of fine art based on scientific discoveries such as multi-dimensional space. Kulbin and Matyushin believed that basic concepts in music-dissonance and consonance-were relative concepts. Yet their Italian colleagues recognized both concepts in a dialectical way, as two sides of the universe. Dissonance, as well as consonance, could be observed and affected various levels: geometric shape (circle/broken line), the physical quantity of matter (resting energy/active energy), or even philosophical perceptions of the world (death/life). Music sound itself is considered a combination of the different pitches that are directly interrelated to a certain combination of colors. Changing the pitch causes a change in the warmness, coldness, or depth of color along with the geometrical shape.

${ }^{47}$ Matyushin, The Creative Way of an Artist, 23. 


\section{Three Names of Russian Futurism in Music}

\section{Abstract}

Filippo Marinetti in his Beyond Communism (1920) called Futurism the official art of Soviet Russia. What is Futurist art in the viewpoint of Russia? Defining art as "a source of power and transformation," Russians believed that it is essential to arrange human society in a new way to create unified art.

This paper deals with the viewpoints of Nikolai Kulbin (1868-1917), Arthur Lourie (1891-1966), and Mikhail Matyushin (1861-1934). Having joined the Futurism movement during a certain period, their art concepts found a reflection in the form of an essay that the current paper is based on.

\section{Tři jména ruského futurismu v hudbě}

\section{Abstrakt}

Filippo Marinetti ve své knize Za branicemi komunismu (1920) nazýval futurismus oficiálním uměním sovětského Ruska. Co je futuristické umění pohledem Ruska? Rusové, když definovali umění jako „zdroj síly a transformace“, věrili, že k tvorbě spojeného umění je stěžejní nové uspořádání lidské společnosti. Tato studie se zabývá stanovisky Nikolaje Kulbina (1868-1917), Arthura Lourié (1891-1966) a Michaila Matyušina (1861-1934). Připojili se k hnutí futurismu a jejich koncepce umění vyústily v reflexi ve formě esejů, z nichž tato studie vychází.

\section{Keywords}

Futurism; Kulbin; Lourie; Matyushin; Unified Art

\section{Klíčová slova}

futurismus; Kulbin; Lourié; Matyušin; spojené umění

Lyudmila Gauk

HK (Humanities of Korea) Music Research Institute

61-6, Yeonhui-ro 15an-gil, Seodaemun-gu, Seoul

South Korea

mila_kalinova@mail.ru 